\title{
Exploring the Civic Identities of Latina/o High School Students: Reframing the Historical Narrative
}

\author{
Cinthia Salinas \\ University of Texas at Austin \\ U. S. A. \\ Jeannette D. Alarcón \\ The University of North Carolina, Greensboro
}

U. S. A.

\begin{abstract}
Notions of citizenship, as taught through the official state curriculum, are narrow and fail to consider the importance of histories that reveal a composite of diverse races/ethnicities, multiple languages, and complex patterns of immigration and transnationalism. The richness of such histories embodies the experiences and contributions of Latinas/os along the geopolitical border of the United States and Mexico. This qualitative case study analysis focuses attention on the teaching and learning practices and experiences in a secondary classroom serving late arrival immigrant students. The teacher and students willingly trouble the existing historical narrative and consequently insert other perspectives and civic identities into said narrative. The uses of more critical notions of historical inquiry and knowledge of the historical narrative as a cultural tool are vital in disrupting traditional histories and themes, thus promoting civic participation among marginalized communities.
\end{abstract}

KEYWORDS: diverse histories, Latinola issues, secondary teaching, citizenship education, late-arrival immigrants

Including the Civic Identities of Late Arrival Immigrants
Theoretical Framework
Method of Inquiry
Findings
Discussion
Conclusion
Notes
References
Author Contact

Our nation's mosaic of linguistic and cultural diversity among public school students presents educators with opportunities to promote more pluralistic ideals of citizenship. In fact, the struggle for citizenship is "animated not by those already secured within the mainstream, not by those privileged largely, but by those not secured and not privileged, by those living at the margins...today by African Americans, Latinos, American Indians..." (Parker, 1996, p. 21). However, for Latinas/os ${ }^{1}$, traditional notions of citizenship, as reflected and embedded in the official history curriculum, are narrow and fail to consider a longstanding 
history of multiple languages, races/ethnicities, and patterns or immigration and transnationalism (Guajardo \& Guarjardo, 2004; San Miguel, 2011). Indeed, since the ratification and rejection of particular articles of the Treaty of Guadalupe Hidalgo in 1848, the rights and privileges of Latinas/os have remained elusive as a result of inferior and segregated schools for Mexican American children, English-only laws, ideological assault upon bilingual education campaigns, and xenophobic responses to the Development, Relief, and Education for Alien Minors (DREAM Act) (Gross, 2013; San Miguel \& Valencia, 1998). Though there exists a history of organized resistance, successful litigation, and even President Obama's recent deportation-reprieve program for young DREAMers, the enduring tensions beg social studies educators to explore the civic identities and histories of Latinas/os.

Despite the opportunities to focus upon the agentic histories of Latinas/os as well as other marginalized communities, citizenship as embedded in the official school curriculum is an exclusively White, male, and propertied construct reflected not only in the beliefs and values of the founding fathers but in the very civic documents that proclaim the rights and privileges of democracy (Loewen, 1995; Takaki, 1993; Zinn, 1997). Decidedly, the story of America is one of progress and individual triumph and not one that openly confronts those histories that any community and nation would find difficult or uncomfortable to tell and scrutinize (Barton \& Levstik, 2004; Epstein, 2009; VanSledright, 2008). By difficult histories we mean those historical accounts that expose accounts of conflict among dominant groups and those that would favor a more equitable political, social, and economic landscape. We further characterize the teaching of difficult histories as those practices that expose the enduring presence of racism, classism, sexism, and other such issues that define the struggle for citizenship as continual.

A notable body of work examines the content (e.g., Evans, 2004; Nash, Crabtree \& Dunn, 1997) and calls for practices that challenge teaching history in more race, class, and gender conscious ways (e.g., Epstein, 2009; Levstik, 2000). Likewise, others have begun to explore ways to construct a more inclusive curriculum (e.g., Salinas, 2006) as well as instructional approaches that openly address issues of racism, classism, sexism, and so forth (e.g., Boltatz, 2006; Salinas \& Blevins, 2012). These scholars argue that history classrooms may be focal spaces for developing a critical and democratic citizenry-"sites of contestation, negotiation, and struggle" that prompt teachers to examine both the ideological and pedagogical practices that emphasize access and claims of citizenship (Rosaldo, 1997, p. 36). In this qualitative case study, we examine the experiences of Latina/o late arrival immigrant high school students and their teacher in an American History classroom and ask when and how do Latinas/os explore their civic identities? Analysis of class observations, interviews, and artifacts indicated that within the parameters of an official school curriculum and state-level exam, the dynamics of the classroom were both compliant and resistant to dominant narratives and renditions of history. However, we also found nuances of how citizenship can be developed by teachers and students through more critical understandings of historical inquiry. 


\section{Including the Civic Identities of Late Arrival Immigrants}

There can be little doubt that the United States has had a longstanding history of differentiating citizenship through race and ethnicity (and class, gender, language, and phenotype) that ignores Latina/o lives along porous and transnational boundaries (Portes \& Rambaut, 2006; Suárez-Orozco, SuárezOrozco, \& Todorava, 2008). Flores and Benmayor (1997) explain that Latinas/os (even those afforded "legal" status) have never enjoyed the rights of full and equal citizenship because the nature of their civic identity is entwined with the outward marks of ethnicity, language, and legal status and with a disregard for a history of oppression and geopolitical tensions. The absence of such historical perspectives results in a failure to provide vivid and enduring portraits of Latinas/os as citizens engaged in acts of democratic deliberation and resistance.

\section{The Challenge of the Historical and Civic Identity of Latinas/os}

The racialized nature of citizenship reveals the challenges encountered by Latina/o late arrival immigrants in social studies classrooms. Urrieta (2004) explains how the United States worked to create the inferior image of Mexicans in northern territories (the lands today known as Arizona, California, Colorado, Nevada, New Mexico, Texas, and parts of Utah) in ways that were dehumanizing and consequently justified the aggression of Manifest Destiny. "Race in the Southwest was produced through practices of Jim Crow, which were not based explicitly on race but rather on language and cultural inextricably tied to race" (Gross, 2013, p. 154). Likewise, contemporary views of citizenship reflect a pervasive public discourse that casts Mexican Americans/Mexican immigrants as "aliens" or "illegals" and positions them as "strangers in their own land" (Takaki, 1993). As San Miguel (1999) described "Anglocentric" history textbooks, he argued they "contained only disparaging comments about the Mexican presence in the Southwest" (p.44). He adds, when describing the historical narrative, that "little to nothing transpired in Texas worthy of record before the coming of the first Anglo settlers from the United States" (p. 45). Indeed an exclusive and narrow "band of brethren" defining citizenship diminishes the histories and possibility of a politically and culturally diverse citizenry (Parker, 1996).

Ironically, multiple Latina/o civil rights groups including the Mexican American Legal Defense and Educational Fund (MALDEF), League of United Latin American Citizens (LULAC), the GI Forum, Mexican American Youth Organization (MAYO), and the United Farm Workers of America (UFWA) have certainly made significant contributions to the history and civic identity of Latina/o communities. Likewise, important individuals like Dolores Huerta, Sylvia Mendez, Juan Seguin, Tomás Rivera, and Emma Tenayuca have articulated valuable campaigns and taken admirable stances on behalf of Latinas/os during the long 
movimiento (Salinas, Naseem Rodriguez, \& Ayala Lewis, 2015). Importantly, the complexity of the Latina/o identity, linked to the "notion of mextizaje, or racial mixture," reinforces the need for communal activity toward the greater good (Gross, 2013, p. 157). Guajardo and Guajardo (2004), in their oral history collection that documents the experiences of Chicana/os students during the 1968 walkouts in the Edcouch Elsa school district in Texas, conclude that "the need for change is critically important because it relates to issues of representation, advocacy, and resources..." (p. 523). The composite narrative of the struggle for civil rights that stretches from before 1848 to contemporary times provides exemplars and renditions of an active Latina/o citizenry. ${ }^{2}$

A rich and long history also exemplifies Latina/o entry into the political fray, acts of civil disobedience, and deliberation and other participatory practices that have melded culture and citizenship. In this sense we adhere to Parker's call for greater attention to the politics of recognition that resists assimilation in lieu of pluralism (Parker, 1996). In particular, we focus attention upon the Latina/o community's right to sustain their own identity and history, and belong to the dominant national community (Knight Abowitz \& Harnish, 2006). Cultural citizenship resists depictions of historical knowledge as neutral (Apple, 2004) and acknowledges the sociocultural and ideological positionality that is inherent to constructing other histories (Banks, 1993). "The perspective of cultural citizenship allows for excluded groups to establish themselves as distinct communities with distinct social claims, while still situating themselves in the broad context of continental American society" (Flores \& Benmayor, 1997, p. 16). The complexity of Latino/s civic identities and histories inevitably also highlights great contradictions and tensions within the community, including the intersectionality of race and gender (Delgado Bernal, Elenes, Godinez, \& Villenas, 2006), and furthers the need to examine the histories and civic identities forged by Latinas/os in America. Regardless, it is the kinship of the mestizos that pulls from the histories of the invasion of Mexico by Cortés to the illegal entry of Whites into the Southwest portions of Mexico to the failure to honor the Treaty of Guadalupe Hidalgo and presents citizenship as immutable from culture (Flores \& Benmayor, 1997; Rosaldo, 1997).

\section{Using Historical Inquiry in Defiance of the Curriculum}

Unfortunately, rarely are such Latinas/os' histories and identities as citizens included in the telling of American history. Consequently, reconceptualizing citizenship education also includes attention to the problematic nature of the historical narrative. In and of themselves, the dominant narrative organizes our telling of history and presents events in a form that is familiar to us: with a beginning, middle and end (Barton \& Levstik, 2004). However, much has been written troubling the historical narrative. Social studies educators have long argued that mythologizing (Kohl, 1994) and/or "heroifying" (Loewen, 1995) historical figures and events is a deliberate and unfortunate merging of history 
and heritage. Several have noted that building a nation through a glorious and unblemished collection of historical narratives that highlight individual achievement, motivation, national freedom, and progress exposes the Americanizing function of the school curriculum (Barton \& Levstik, 2004; VanSledright, 2008). The consequence of such inaccuracies presents students with a poor understanding of the past.

For Latinas/os, including late arrival immigrants, the historical narrative that instills notions of citizenship is not probable-what Wertsch (2000) describes as "knowing but not believing" and "not knowing but believing" (p.39). While late arrival immigrants may be introduced to these narratives, they are doubtful of their "truth." Late arrival immigrants come to school with knowledge that is not affirmed by the official school curriculum. Thus while the dominant historical narrative and curriculum calls for students to "remember the Alamo," many late arrival immigrants from Mexico remain puzzled and more inclined to "forget the Alamo" (Salinas, 2006).

Wertsch (2000) further argues that students may master the narrative content but they do not necessarily appropriate its content. In this sense it is possible for late arrival immigrant students to master this dominant narrative-to perform well on exams and course work-but also to resist appropriation and instead continue to consider other narratives that resonate with greater truth. Essentially, the most valued approach to learning history and the role of citizens in history should attend not to what teachers must teach and students must learn but rather to the examination and interpretation of historical evidence that yields complex and/or contrasting histories (Blevins \& Salinas, 2012; Wineburg \& Wilson, 2001).

A flurry of attention has been directed towards the use of historical inquiry, the evidentiary trail and perspective-taking that can be revealed in primary sources like letters, journal entries, photographs, public documents, and other first-hand accounts (Barton \& Levstik, 2004; Wineburg, 2001; VanSledright, 2002). Notably, historical inquiry is a "cultural act that teaches students about warrants, about the nature of understanding, and about their role in making historical knowledge" (Stearns, Seixas, \& Wineburg, 2000, p.3) Subsequently, critical historical inquiry presents a substantial opportunity to disrupt the historical narrative, promote counter-narratives, and expose acts of racism, classism, and sexism empowering marginalized communities (Boltatz, 2006; Salinas, Blevins \& Sullivan, 2012; Sterns, Seixas, \& Wineburg, 2000). Moreover, engaging in critical historical inquiry promotes an understanding of the author's interpretation and metanarrative, and attends to the notions of privileged knowledge (Apple, 2004) as well as the epistemic nature of historical positionality (Banks, 1993; Salinas \& Blevins, 2014). In sum, teachers and students engage in the process of constructing, not simply consuming, a historical narrative. With inquiry, teachers and students discover an intimate relationship between their own ideological stance and historical positionality and the writing of the historical narrative. Late arrival immigrants and their teachers cannot avoid dominant historical narratives, 
but they can interrogate and resist them if the knowledge and experiences they find essential is considered viable (Salinas, Blevins, \& Sullivan, 2012).

\section{Theoretical Framework}

In order to examine the experiences of Latina/o late arrival immigrant high school students and their teachers in an American History classroom and ask when and how Latinas/os explore their civic identities, we frame our inquiry within the sociocultural context of the classroom. By sociocultural we mean that the construction of the historical narrative is "related to cultural, institutional, and historical context" (Wertsch, 2000, p. 3). The dynamic we argue opens viable spaces for teachers and students to enact the history curriculum and civic identities in much more inclusive and critical ways. When teachers juxtapose the technical or the official/dominant curriculum to the curriculum in use or the enacted curriculum that emerges in a classroom, building a critical citizenry becomes more transparent and subject to critical examination (Cornbleth, 1985; Quijada Cerecer, Alvarez Gutiérrez \& Rios, 2010). The navigation between differing interpretations of history and added perspectives highlights an understanding of the "mediation of school knowledge, and on the contradictions of school experience" (Cornbleth, 1985, p.39). Consequently, we readily examine the use of historical inquiry and teachers' and students' abilities to interrupt the dominant historical narrative and present in contrast other histories and civic identities.

Engaging in historical inquiry cannot ensure that notions of race, class, gender, and so forth will be central to the essential questions or pursuit of the evidentiary trail. "Thus we maintain that "controversial" histories-those that are silenced or avoided - form the very elements of critical historical thinking that can distinguish our American identity and plurality in the most meaningful ways" (Salinas et al., 2012, p. 20). Critical historical inquiry directly recognizes that a historical narrative is not neutral. The process of engaging in perspective-taking then openly acknowledges that narratives are much more complex and nuanced if not contrary and oppositional. Second, important to the use of historical inquiry is how social studies/history teachers understand the narrative and counternarrative and how their own ideologies are fundamental in selecting and shaping lessons to fit their students' needs (Ball \& Cohen, 1996; Salinas \& Sullivan, 2007). In this sense, students' and teachers' positionality comes into play and helps to decide what evidence is gathered, organized, and interpreted in engaging in historical inquiry and constructing a historical narrative. Finally, by emphasizing historical positionality (VanSledright, 2002) or historical funds of knowledge, we also attend to how students' own experiences contribute to acceptance/rejection of cultural tools such as the dominant historical narrative. Conceding that teachers and students may perhaps be inundated by problematic historical narratives but do not necessarily succumb to them allows for empowering pedagogies to emerge and expose the "irreducible tension between 
the cultural tool and an agent's use of it" (Wertsch, 2000, p. 98). In this project, we focus attention on teaching and learning history and citizenship in a late arrival immigrant social studies classroom. We argue that teachers with a fluent knowledge of both the official and counter versions of the historical narrative make conscious decisions that allow their students to resist appropriation and develop alternative conceptualizations of history and citizenship.

\section{Method of Inquiry}

Located in a midsize central Texas city, Peńa High School was a relatively new, large high school (2800 students enrolled) and had a 92\% minority enrollment (predominately Latinas/o) with more than $20 \%$ of the students signified as Limited English Proficient (TEA, 2011). In the fall of 2011, as a team of social studies educators ${ }^{3}$, we began a qualitative case study examination of a reconceptualized American History (post-Reconstruction) curriculum found in the late arrival social studies classroom. The bounded system that included this curriculum enacted by the teacher and students was instrumental to our analysis of a broadened understanding of American history, its interaction (or enactment) with late arrival immigrant students, and more complex notions of history and citizenship. Therefore, the instrumental case study approach allowed researchers the opportunity to use multiple data sources in describing the reconceptualization of citizenship education for late arrival immigrant students in a social studies classroom context specifically designated for them at Peńa H.S. Researchers focused on the experiences of Latina/o late arrival immigrant high school students and their teacher in an American history classroom and asked when and how civic identities are explored.

\section{Positionality}

It is important to note that as Latinas and social studies educators, we initially position ourselves as insiders understanding the kinship of Mexicans/Mexican Americans. We know our ancestral histories are marginalized and our civic identities diminished through the official school curriculum. However, neither of us are immigrants or the children of immigrants, nor did we experience the label of English language learner. We acknowledge our own privilege and call upon our community's intra group differences, border crossing identities, and mestizaje in ways that are empowering and informed by our Chicana epistemologies. 


\section{Participants}

The American History Studies (post Reconstruction) classrooms included 12 late arrival immigrant students including 10 from Mexico, one from Honduras, and one from Venezuela. In the two previous years, four of the students had attended the school district's designated international campus ${ }^{4}$ but the other eight in the two previous years had taken both World Geography and World History with the teacher, Ms. Alcala. A $3^{\text {rd }}$ generation Mexican American (she interchangeably called herself Chicana), Ms. Alcala had taught for 12 years, all in secondary English as a Second Language (ESL) social studies contexts. Her familiarity with the students and essential instructional approaches, and her constant "troubling" of the official school curriculum, made the classroom an ideal space for examining how curriculum emerges as a dynamic sociocultural space. Moreover, Ms. Alcala's thorough understanding of critical pedagogies allowed for a conscious critique of the official historical narrative and the centering of cultural citizenship and more critical uses of historical inquiry.

\section{Study Context and the History Curriculum}

The research team collaboratively designed three introductory lessons highlighting the pre-Reconstruction American History narratives-course content offered at the $8^{\text {th }}$ grade level. All American History Studies (post-Reconstruction) courses typically began with a quick review of American History Studies (preReconstruction history, 1604-1865). The unique challenge was that the late arrival immigrants had not completed this or a similar course in their home countries, and the pre-Reconstruction American history material was essential to understanding much of post-Reconstruction American history. For late arrival immigrants, the review material was actually an introduction to the American narrative and to the history of citizenship.

First, using an interactive Prezi presentation over the span of two class sessions (90 minutes each), students were introduced through primary sources (all visual or with minimal text to aid the second language learners; see Szpara \& Ahmad, 2007) and scaffolding document-based questions (DBQs) to a review of American history beginning with Jamestown and culminating in early sectionalism debates of the 1820s. After moving through the presentation and answering the DBQs, students placed the primary sources in chronological order via the Prezi and also by manipulating printed copies of the primary sources. In contrast, the second lessons (also two 90-minute class sessions) focused greater attention on the use of the Mexican American War as a mechanism for Manifest Destiny and in connection with the sectionalism (slave/non-slave states) rush to statehood. Students engaged in a second close read of the primary source documents, and DBQs served to scaffold the students' interpretations of them. In 
the culminating lesson, students used a Jog the Web activity (a collection of preset web sites and accompanying questions) to further the students' interpretations through open-ended questions regarding the historical period. Particular questions focused upon the Mexican American War including (a) What went wrong with the Treaty of Guadalupe Hidalgo (1848)?; (b) Suddenly after the Treaty of Hidalgo-Mexican citizens were now American citizens (maybe given the rejection of particular treaty articles) - how did they feel? (c) What is a citizen?; and (d) How might you be very much like the Mexicans turned American's in 1848 ?

\section{Data Gathering and Analysis}

Student responses to the Jog the Web activity, field notes from lesson sessions, and teacher pre and post interviews (digitally recorded) on lesson design and curriculum choices were included in this analysis. Data sources were analyzed collectively. Following Miles, Huberman, and Saldaña (1994), the data analysis proceeded from noting patterns and themes to arriving at comparisons and contrasts to determining conceptual explanations of the data. In noting patterns and themes, we not only sought rich descriptions but also explanations. For example, researchers discussed the existence of both official and counter histories in use that the teacher and students readily distinguished.

\section{Findings}

This findings section shares three emergent themes from the data analysis. First, the authors present information evidencing Ms. Alcala's decisionmaking processes for moving from more traditional historical content to materials that were more representative of the histories of her students. Next, we present moments when the students responded to the change. Last, we present data leading to a more nuanced understanding of civic activity.

\section{More Critical Notions of Teaching History}

One could immediately note an overt presence of an official historical curriculum and undeniable feelings of pressure associated with the standardized curriculum and state level exams. Ms. Alcala struggled daily (literally) to align her ambitions for her students with the state standards, the district's scope and sequence, and bi-monthly standardized mini-evaluations that were matched to the state exam (Grant, 2003). Her small office, shared with two other teachers, included a bookshelf that housed multiple manuals and guidebooks used for assessing ESL students, a binder with the state curriculum standards-the Texas 
Essential Knowledge and Skills (TEKS); the district-issued textbooks for World Geography, World History, and American History; several commercial curriculum packages (e.g., History Alive); and stacks of district-issued scope and sequence documents; and benchmark practice exams. An overwhelming presence of the official curriculum seemed to steer her resources as a social studies teacher.

In deciding how to proceed with the pre-Reconstruction American History review design, Ms. Alcala explained during an initial planning session, "I have to plan based on the district map that has the American history TEKS (state curriculum standards) but I also check out the questions from the bi-monthly evaluations the district wants us to give as benchmark preparation and I also have these PowerPoints that my colleagues gave me" (interview 8/22/11). On one hand, as she laid out each of the lesson of the curricula, there was little doubt that Ms. Alcala was aware of the weight of explicitly specified objectives, content, materials, and activities that were assembled for classroom teachers and their students (Cornbleth, 1985). Her thinking became a list of topics and vocabulary words that she felt compelled to use in her lesson planning. In scanning the almost random list, it was difficult to discern the valuable social studies ideas or questions. Instead the list of topics, while driven by the stateand district-mandated curriculum, became her attempt to legitimize if not "perform" her own curricular decisions to administrators and colleagues. In other words, her planning, on the surface, did not evidence the deeper ways in which she hoped to address notions of history and citizenship.

On the other hand, despite the list and public performance, Ms. Alcala also noted with vehemence that for the late arrival immigrant students she would need to depart from the mandated curriculum found on her bookshelf and desk. The list then may have given her legitimacy with her colleagues, principal, district, and the state, but it was hardly telling of what she felt was at stake in her decision-making. Ms. Alcala's practices were framed by some clear ideologies and ambitions. At first glance, for example, the design of her first lesson built the grand narrative of early America spanning from the Jamestown expedition, colonization, independence, expansionism, and sectionalism leading to the Mexican American War.

In fact, Ms. Alcala often made many decisions that leaned away from official demands and narratives. Ms. Alcala held a particular stance towards the official curricula - one that subtly/obviously differed from the traditional narrative by working to expose a culture of power and ideology that often accompanied the teaching of history and depiction of others (Sleeter, 2008). She was unapologetic in saying,

I know the curriculum is all about how great America is and it just ignores all the bad stuff we have done in the past and all the ways that others contributed to this country. They have to learn how to contribute and how to critique. If I can show the kids to be more aware, I feel I have done my job (interview 9/2/11). 
In this sense, the choices made by Ms. Alcala also introduced atrocities as well as disregard for others that were not part of the official or planned historical narrative. For instance, in discussing the Royal Proclamation of 1763 and the Louisiana Purchase, she made evident through notions of empathy (caring) the hardship that must have been incurred by the indigenous tribes of the Americas. She asked, "Why would the Iroquois take sides with the French and not British? How might the indigenous tribes have reacted to the creation of the first Indian Reservation?" Ms. Alcala purposely designed historical inquiry so that students could see beyond the glorious victory of the French-Indian War and the acquisition of the Louisiana territories and instead consider the consequences for the indigenous peoples during that period of history. These primary sources/visual images and DBQs appeared at opportune moments. She worked to take advantage of spaces in the curriculum that allowed for an offering of other narratives or counter-narratives. She expressed what Bell (2003) terms "historical positionality" when she explained, "There is only so much time but there are just some perspectives you have to insert-the students know something is missing" (interview, 8/29/11). Conscious and knowledgeable of history and her students' own understandings and experiences, she allowed her worldview and her students' worldview to matter in the teaching and learning of history (VanSledright, 2002).

\section{When Students Engage with Critical Historical Inquiry}

With each lesson, the late arrival immigrant students engaged in critical notions of historical inquiry and notions of citizenship as Ms. Alcala had hoped. Through deliberate curricular decisions, the use of primary sources and DBQs provided valuable support for conversations regarding a history of racism, sexism, and classism. For example, the commonly used painting by J. Ferris (1915) depicting the Pilgrims generously offering food and hospitality to the Wampanoag generated much discussion when Ms. Alcala asked, "Who is serving whom and do you believe this is an accurate?" One of the students, Kevin, jumped in quickly to say "No. The Indians they are ones that knew how to cook and hunt and grow things... it is just not right to think that the Pilgrims were going to take care and be so nice to the Indians." Eduardo, another student, added, "Yeah-you know the Pilgrims ended up killing all those Indians and taking their land. That picture is not what you would think." Nancy was confused when she said, "Why did they do that-pretend to be all nice and then kill them?" Ms. Alcala interjected, saying, "Eventually-over time-there is a genocide, a mass killing, of the indigenous people but that comes as the Colonists and then Americans want more land" (class observation field notes 8/31/11). As observers we were aware of the inaccuracy and inflammatory conclusions reached by some of the students, but we also noted the ease with which the students took up issues of genocide and racism. Moreover we noted that the students were not allowing the Pilgrims to be presented in such a way without interrupting or questioning the logic or substance of the narrative (Wertsch, 2004). 
There was a second example that deserves our attention, a subsequent Jog the Web activity that included visual images and questions regarding the Mexican American War. A map of the Mexican-US border indicating which lands were taken by the United States in the Treaty of Guadalupe Hidalgo' incited great response. Ms. Alcala had predicted as much. The students again had no problem understanding the aggressive history of the United States and the exclusion of rights of citizenship-driven by Manifest Destiny and sectionalism. Hugo wrote on this assignment prompt regarding the causes and consequences of the Mexican American War, "Because America wanted more-territory that belonged to other countries and to expand their civilization and more money for themselves." Alexis's response indicated, "The US thought God was on their side and so they should just take more land. They also wanted more slaves." Finally, Erik struck a powerful note when he wrote, "I think the causes of the civil war are the slavery and maybe the racist and I think the cause for the civil war was the injustices..." (Classroom artifact, 9/2/11). The student interpretations of the primary sources make apparent at least one point regarding Ms. Alcala and her students - that given the opportunity to examine other perspectives students can develop a critical understanding history (Fránquiz \& Salinas, 2011; Fránquiz \& Salinas, 2013).

\section{Understanding Civic Identities}

Ms. Alcala and her students resisted official historical narratives and created unique spaces and more powerful renditions of civic identities and histories. In describing how Mexican citizens might have felt after the Treaty of Hidalgo, ${ }^{5}$ the students reached a quick consensus that the new MexicanAmericans felt "confused, disappointed, abused, and betrayed" (classroom observation, 9/2/11). However, when asked to write about the meaning of citizenship, students responded in an array of ways. First, many simply stated that you could only be a citizen by birthright and consequently noted their allegiance for their home countries. For example, Kevin wrote, "A citizen is when you are original to a country. Like me. I am from Honduras. So I am a citizen because I [was] born in that country." Kevin's revealed his allegiance to a singular nation state negating a transnational civic identity (Knight Abowitz \& Harnish, 2006). Hugo made a similar claim in writing, "A citizen is when you born in any country." Kevin and Hugo might have embraced a transnational ideal of citizenship or revealed how citizenship can be complicated by events or voluntary/involuntary migrations, but instead remained steadfast to this narrow construct of citizenship. These students' expressed membership to the political community was rooted in their home countries and consequently negated the complex histories of citizenship taught by Ms. Alcala (see also Westheimer \& Khane, 2004).

A second type of student explanations of citizenship noted more legalese explanations in saying, "Para ser ciudadano Americano tienes que llegar a los 
Estados Unidos de 5 anos para ariba para poder acer ciudadano Americano" (To be a citizen of America you need to arrive in the United State for five years in order to be an American citizen) (Maria, classroom artifact, 9/2/11). Her reference to "five years" was to the immigration legislative efforts like the Immigration Reform and Control Act or the Simpson-Mazzoli Act of 1986 that were discussed in class. Alexis also wrote with the same kind of references a discourse found in texts. "Be a citizen means you have the rights that the constitution give to citizens...the citizen deserves all the rights..." (Alexis, classroom artifact, 9/2/11). Nancy added, "Para mi ser un ciudadano significa que tienes la libertad para estar en tu pais legalmente, que tienes sus ideas, costumbres, y tradiciones" (To me you are a citizen when you are free to be in your country legally and have ideas, customs and traditions) (Nancy, classroom artifact, 9/2/11). Here Maria and Nancy revealed the tensions experienced by immigrants or hinted at a manifestation of cultural citizenship. However one could equally argue that in general these explanations seemed attached to 'textbook' or official understandings of citizenship. Moreover, the definition did not cite the complexity of citizenship for the indigenous peoples of the Americas, for Mexicans after the war, or for the lives they and their families were living as late arrival immigrants.

In contrast, several of the explanations did draw explicit comparisons between themselves and the Mexican-Americans of 1848 and consequently presented much more complex understandings of citizenship. Nancy for example continued "Me sentiria mal si cambian mi nacionalidad...que tengo mis costumbres asi que seria complicado y la verdad no me gustaria" (I feel bad if I had to change nationality like them...I have my customs and so it would be complicated and in truth I would not like it) (Nancy, classroom artifact, 9/2/11). Alexis added, "This was obviously wrong. The war never bring something good...the government caused cultural division and future problems as well" (Alexis, classroom artifact, 9/2/11). These final types of comments indicate that some of the students had come to embrace more advanced ideals of citizenship and were able to draw meaningful connections between themselves and other marginalized communities in history. Ultimately, the students expressed understandings that drew from multiple experiences and their interpretation of history and the civic identities common to the United States.

\section{Discussion}

A late arrival immigrant social studies classroom potentially provides an ideal space for exploring tensions between the official curriculum and transformative practices of a socially just democracy to emerge. As a qualitative study of any single late arrival immigrant classroom, there are limitations that we acknowledge, including the predominant attention to the geopolitical histories between Texas and Mexico. However, a sociocultural analysis of teacher and her late arrival immigrant students engaged in the teaching and learning of more 
critical understandings of American history can shed light on the complexity of Latinas/os civic identities. As Apple (1992) explains,

We cannot assume that what is in the text is actually taught. Nor can we assume that what is taught is actually learned. Teachers have a long history of mediating and transforming text material....Students bring their own classed, raced, and gendered biographies with them as well. (p. 10)

We contend that selection/exposure of certain histories and use of historical inquiry is fundamental in fostering the development of a critical classroom dialogue. Social studies teachers may adhere to the celebratory and progressive themes that silence or avoid conflicts surrounding race, class, and gender. Or social studies teachers may instead skillfully lead students in questioning dominant historical interpretations by introducing difficult histories. Exposing the enduring presence of racism, classism, sexism and so forth that define the struggle for citizenship as continual can serve as a catalyst for exchanges regarding historical perspective and civic identity.

One may argue that the historical narrative as the story of how a nation's citizenry either furthers or thwarts a democratic and just society is central to developing another generation of critical and participatory citizens. The social studies classroom provides an avenue for exploring such understandings of history that are intimately linked to how citizens have acted in the past and may act in contemporary settings. Regrettably, the dominant story conveys a rigid chain of events and causal relationships leaving little room for alternative, contrary, or complex interpretations (Salinas, Blevins \& Sullivan, 2012). Problematizing the narrative through historical inquiry in late arrival immigrant social studies classrooms serves two general purposes. Initially it provides knowledge that is not otherwise accessible through the official curriculum. Images of the benevolent Pilgrims and a godlike rendition of Manifest Destiny are within the reach of teacher's curricular choices and young students' critical lens. In addition, though controlled by the dominant culture in support of their own status and beliefs. "Citizenship education... is not solely under the command of privileged groups, however, but also of marginalized groups who struggle for access to power and, in the case of oppressed groups, a decent and respected life" (Parker, 2008, p. 66). In developing the critical lens of late arrival immigrants, we empower marginalized groups and their civic identities, and advance critical pedagogies.

\section{Conclusion}

Findings from the classroom observations, interviews, student artifacts, and teacher's materials suggested that the teacher and late arrival immigrant students who participated in this study took up a space to consider multiple perspectives related to both notions of citizenship and the dominant historical narrative presented in U.S. high schools. As we gathered data in this classroom 
and engaged in conversations with the teacher, we began to realize the complexities not only of Ms. Alcala's instructional decision-making but of the classroom dynamics as well. During any given lesson, Ms. Alcala was accelerating knowledge construction by including background knowledge that her students' peers had learned in middle school, scaffolding them toward mastery of standard, academic English, and introducing and complicating the official knowledge constructs outlined in the state-mandated curriculum and district curriculum guides.

The implications are twofold. First, the official curriculum can remain a technical and mandated body of knowledge or it can become a dynamic exchange between teachers and their students open to critical examination that exposes fundamental flaws and more inclusive perspectives. Second, the teaching of history can promote the histories and citizenry of the narrow 'band of brethren' or can provide histories and possibilities for a politically and culturally diverse citizenry. In both cases we hope that teachers and teacher educators consider the latter as a way to build a citizenry well prepared for our pluralist democracy. Kevin, Nancy, Maria and the other students expressed concern for people who are not given voice in decision making in both contemporary and historical contexts These future citizens exhibited the desire to understand the relevance of the events they were studying while also seeking to understand their place within the narrative.

As educational researchers and teacher educators, we seized the opportunity to examine these aspects of classroom life in order to more fully understand the components at play in late arrival immigrant social studies classrooms. While unpacking these complexities remains an ongoing process, the study findings demonstrate the importance of ensuring that teachers are exposed to counter historical narratives and develop strategies for incorporating this knowledge and models of citizenry into their pedagogies. The long-term work of this project includes an ongoing development of such learning experiences for social studies teachers and continued work toward complicating histories and civic identities.

\section{Notes}

1. The term Latina/o is used to imply political and ideological consciousness between those who share origins to colonized Spanish speaking countries in the Americas. However, we emphasize the significant intra group differences of Latinas/os and note that both the authors and most of the participants in the study are of Mexican descent.

2. See San Miguel (2010): their legal history as citizens (e.g., Independent School District V. Salatierra (1930); Mendez v. Westminster School District (1946); Cisneros v. Corpus Christi Independent School District (1970/71); and Keyes v. School District Number One (1973/75) 
3. The data set is part of a larger project/subprojects (start date 2004) that included Language Arts/Bilingual Education colleagues and research in several secondary school sites in Texas that serve late arrival immigrant students. Only social studies data in a singular site is included in this discussion.

4. In general, late arrival immigrants are either integrated into regular classes, enrolled in sheltered language classrooms in core content areas, or attend for a short period of time a singular campus designated for late arrival immigrants.

5. It is important to note that the Treaty of Mesilla, which concluded the Gadsden Purchase of 1854 , settled unresolved territorial disputes after the Treaty of Hidalgo.

\section{References}

Apple, M. W. (1992). The text and cultural politics. Educational Researcher, 21 (7), 4-11,19.

Apple, M. W. (2004). Ideology and curriculum. New York, NY: Routledge Falmer.

Banks, J. (1993). The canon debate, knowledge construction, and multicultural education. Educational Researcher, 22(5), 4-14.

Ball, D. L., \& Cohen, D. K. (1996). Reform by the book: What is-or might bethe role of curriculum materials in teacher learning and instructional reform? Educational Researcher, 25(9), 6-8, 14.

Barton, B., \& Levstik, L. (2004). Teaching history for the common good. Mahwah, $\mathrm{NJ}$ : Lawrence Erlbaum Associates.

Bell, L. A. (2003). Telling tales: What stories can teach us about racism. Race, Ethnicity and Education, 6(1), 3-28.

Blevins, B., \& Salinas, C. (2012). Critical notions of historical inquiry: An examination of teacher enactment in history classrooms. Social Educator, $30(2), 13-22$.

Boltatz, J. (2006). Using primary sources with fourth grade students: Talking about racism while preparing for standardized tests. In S. G. Grant (Ed.), Measuring history: Cases of state level testing across the United States (pp. 133-156). Greenwich, CT: Information Age Publishing.

Cornbleth, K. (1985). Reconsidering social studies curriculum. Theory and Research in Social Education, 13(2), 31-45.

Delgado Bernal, D., Elenes, A., Godinez, F. E., \& Villenas, S. (2006). Chicana/Latina education in everyday life: Feminista perspectives on pedagogy and epistemology. New York, NY: State University of New York 
Press.

Epstein, T. (2009). Interpreting national history: Race, identity, and pedagogy in classrooms and communities. New York, NY: Routledge.

Evans, R. (2004). The social studies wars: What should we teach the children? New York, NY: Teacher College Press.

Flores, W., \& Benmayor, R. (1997). Constructing cultural citizenship. In W. Flores \& R. Benmayor (Eds.), Latino cultural citizenship: Claiming identity, space, and rights (pp. 1-23). Boston, MA: Beacon Press.

Fránquiz, M., \& Salinas, C. (2011). Newcomers to the U.S.: Developing historical thinking among Latino immigrant students in a central Texas high school. Bilingual Research Journal, 34, 58-75.

Fránquiz, M., \& Salinas, C., (2013). Knowing English is not enough! Cultivating academic literacies among high school newcomers. The High School Journal, 96(4), 339-357.

Grant, S. G. (2003). History lessons: Teaching, learning, and testing in U.S. high school classrooms. Mahwah, NJ: Lawrence Erlbaum Associates.

Gross, A. J. (2013). The "Caucasian Cloak" Mexican Americans and the politics of Whiteness in the twentieth-century Southwest. In R. Delgado and J. Stefancic (Eds.), Critical Race Theory: The cutting edge $\left(3^{\text {rd }}\right.$ ed., pp. 154166). Philadelphia, PA: Temple University Press.

Guajardo, M., \& Guajardo, F. (2004). The impact of Brown on the Brown of South Texas: A micropolitical perspective on the education of Mexican Americans in a South Texas community. American Educational Research Journal, 41(3), 501-526.

Knight Abowitz, K., \& Harnish, J. (2006). Contemporary discourses of citizenship. Review of Educational Research, 76(4), 653-690.

Kohl, H. (1994). The politics of children's literature: What's wrong with the Rosa Parks myth? In Rethinking our classrooms: Teaching for equity and justice (pp. 137-140). Milwaukee, WI: Rethinking Schools.

Levstik, L. S. (2000). Articulating the silences: Teachers' and adolescents' conceptions of historical significance. In P. Stearns, P. Seixas \& S. Wineburg (Eds.), Knowing, teaching \& learning history: National and international perspectives (pp. 284-305). New York, NY: New York University.

Loewen, J. (1995). Lies my history teacher told me. New York, NY: Simon \& Schuster.

Miles, M. B., Huberman, M. A., \& Saldaña, J. (2014). Qualitative data analysis: A methods sourcebook ( $3^{\text {rd }}$ ed.). Los Angeles, CA: SAGE.

Nash, G. B., Crabtree, C. A., \& Dunn, R. E. (1997). History on trial: Culture wars and the teaching of the past. New York, NY: Knopf. 
Parker, W. C. (1996). "'Advanced' ideas about democracy: Toward a pluralist conception of citizen education," Teachers College Record, 98(1), 104125.

Parker, W. C. (2008). Knowing and doing in democratic citizenship education. In L. Levstik \& Tyson C. (Eds.), Handbook of research in social studies education (pp. 65-80). New York, NY: Routledge.

Portes, A., \& Rambaut, R. (2006). Immigrant America: A portrait ( ${ }^{\text {rd }}$ ed.). Berkley, CA: University of California Press.

Quijada Cerecer, P., Alvarez-Gutierrez, L. \& Rios, F. (2010). Critical multiculturalism: Transformative educational principles and practices. In T. Chapman \& N. Hobbel (Eds.), Social justice pedagogy across the curriculum (pp. 144-163). Hoboken, NJ: Routledge.

Rosaldo, R. (1997). Cultural citizenship, inequality, and multiculturalism. In W. Flores \& Rina Benmayor (Eds.), Latino cultural citizenship: Claiming identity, space, and rights (pp. 1-23). Boston, MA: Beacon Press.

Salinas, C. (2006). Educating late arrival high school immigrant students: A call for a more democratic curriculum. Multicultural Perspectives, 8(1), 20-72.

Salinas, C., Blevins, B., \& Sullivan, C. (2012). Critical historical thinking: When official narratives collide with other narratives. Multicultural Perspectives, 14(1), 18-27.

Salinas, C., \& Blevins, B. (2014). Critical historical inquiry: How might pre-service teachers confront master historical narratives? Social Studies Research and Practice, 9(3), 35-50.

Salinas, C., Naseem Rodriguez, N., \& Ayala Lewis, B. (2015). The Tejano History Curriculum Project: Creating a space for authoring Tejanas/os into the Social Studies curriculum. Bilingual Research Journal, 38, 172-189.

Salinas, C., \& Sullivan, C. (2007). Latina/o teachers and historical positionality: Challenging the construction of the official school knowledge. Journal of Curriculum and Pedagogy, 4(1), 178-199.

San Miguel, G. (1999). The schooling of Mexicanos in the Southwest, 18481891. In J. Moreno (Ed.), The elusive quest for equality: 150 years of Chicano/Chicana education (pp. 31-51). Boston, MA: Harvard Educational Review.

San Miguel, G. (2010). Embracing Latiniddad: Beyond nationalism in the history of education. Journal of Latinos and Education, 10(1), 3-22.

San Miguel, G. \& Valencia, R. (1998). From the Treaty of Guadalupe Hidalgo to Hopwood: The educational plight and struggle of Mexican Americans in the Southwest. Harvard Educational Review, 68(3), 353-412.

Sleeter, C. (2008). Teacher education, neoliberalism, and social justice. In W. Ayers, Quinn, T., \& Stovall, D (Eds.), Handbook of social justice in education (pp. 611-624). New York, NY: Routledge. 
Stearns, P., Seixas, P., \& Wineburg, S. (Eds.). (2000). Knowing, Teaching \& Learning History: National and International Perspectives. New York, NY: New York University.

Szpara, M. Y. \& Ahmad, I. (2007). Supporting English-language learns in social studies class: Results from a study of high school teachers. The Social Studies, 98(5), 189-195.

Suárez-Orozco, C., Suárez-Orozco, M., \& Todorava, I. (2008). Learning a newland: Immigrant students in American society. Cambridge, MA: Harvard University Press.

Takaki, R. (1993). A different mirror: A history of multicultural America. Boston, MA: Little, Brown and Company.

Urrieta, L. (2004). Chicana/o activism and education: An introduction to the special issue. The High School Journal, 87(4), 1-9.

VanSledright, B. (2002). In search of America's past. New York, NY: Teachers College Press.

VanSledright, B. (2008). Narratives of nation-state, historical knowledge, and school history education. Review of Research in Education, 32,109-146.

Wertsch, J. V. (2000). Is it possible to teach beliefs, as well as knowledge about history? In P. N. Stearns, P. Seixas \& S. Wineburg (Eds.), Knowing, Teaching and Learning History: National and International Perspectives (pp. 38-50). New York, NY: New York University Press.

Wertsch, J. V. (2004). Mind as action. Oxford, UK: Oxford University Press.

Westheimer, J. \& Khane, J. (2004). What kind of citizen? The politics of education for democracy. American Educational Research Journal, 41(2), 237-269.

Wineburg, S. (2001). Historical thinking and other unnatural acts: Charting the future of teaching the past. Philadelphia, PA: Temple University Press.

Wineburg, S. \& Wilson, S. M. (2001). Peering at history through different lenses. In S. Wineburg (Ed.), Historical thinking and other unnatural acts: Charting the future of teaching the past (139-154). Philadelphia, PA: Temple University Press.

Zinn, H. (1997). A people's history of the United States, New York, NY: New York Press. 


\section{Author Contact}

Cinthia Salinas, cssalinas@austin.utexas.edu Curriculum and Instruction

The University of Texas, Austin

1 University Station

Austin, TX 78712-0379

U. S. A.

Jeannette D. Alarcón, jdalaco@uncg.edu

Teacher Education and Higher Education

The University of North Carolina, Greensboro

P.O. Box 26170

Greensboro, NC 27402-6170

U. S. A. 